\title{
Circulatory collapse during wound closure in spine surgery with an unknown cause: a possible adverse effect of topical application of vancomycin?
}

\author{
Xiaoqing Zhang, Wenwen Zhai, Min Li and Xiangyang Guo* (B)
}

\begin{abstract}
Background: Vancomycin (VCM) is effective in fighting Gram-positive bacteria related severe infections, and topical application of VCM powder is widely used in orthopedic surgery to prevent wound infection. However, VCM could lead to infusion rate-dependent antibody-and complement-independent anaphylaxis reaction by inducing direct release of histamine.

Case presentation: We retrospectively analyzed seven cases of severe hypotension and shock during wound closure or immediately after orthopedic surgery with unidentifiable reasons. We found that these cases were all associated with local application of VCM powder during wound closure process. Two patients experienced sudden cardiac arrest. Most of the cases (6/7) with circulatory collapse were discharged without severe sequelae. While one case with application of $3 \mathrm{~g}$ VCM developed cardiac arrest and remained in a coma due to hypoxic-hypoxic encephalopathy. The clinical presentations and the time of the shock onset were considered to be related with a VCM induced anaphylaxis reaction. However, as this was a retrospective study, and there was no laboratory examination performed, the conclusion was made upon differential diagnosis based on clinical manifestations and the timing of the shock.

Conclusions: Local application of VCM may not be as safe as was once believed and may lead to a related anaphylaxis. As VCM induced infusion-rate dependent, non-lgE mediated anaphylaxis is characterized by delayed occurrence, severe hypotension and even circulatory collapse, surgeons and anesthesiologists should be extra vigilant during and after VCM application.
\end{abstract}

Keywords: Vancomycin, Hypotension, Shock, Anaphylaxis

\section{Background}

Shock is defined as a state of insufficient perfusion and oxygen delivery to the tissues. The pathophysiology of shock could be simplified to three major components: cardiac function (the pump), intravascular volume (the tank), and systemic vascular resistance (the pipes) [1].

\footnotetext{
* Correspondence: puthmzk@163.com

Department of Anesthesiology, Peking University Third Hospital, No. \# 49, Huayuan Rd; Haidian Dist, Beijing, China
}

Whatever the causes of shock may be, if the impaired perfusion and oxygen delivery is not recognized and reversed, the circulatory collapse may progress into organ dysfunction and failure, tissue necrosis and even death. It is urgent to identify the causes of shock and take immediate measures. However, in critical situations, it is hard to rapidly distinguish the culprit during complex clinical situations. Here we present 7 cases (Table 1) of unidentifiable causes of shock during wound closure or

(C) The Author(s). 2021 Open Access This article is licensed under a Creative Commons Attribution 4.0 International License, which permits use, sharing, adaptation, distribution and reproduction in any medium or format, as long as you give appropriate credit to the original author(s) and the source, provide a link to the Creative Commons licence, and indicate if changes were made. The images or other third party material in this article are included in the article's Creative Commons licence, unless indicated otherwise in a credit line to the material. If material is not included in the article's Creative Commons licence and your intended use is not permitted by statutory regulation or exceeds the permitted use, you will need to obtain permission directly from the copyright holder. To view a copy of this licence, visit http://creativecommons.org/licenses/by/4.0/ The Creative Commons Public Domain Dedication waiver (http://creativecommons.org/publicdomain/zero/1.0/) applies to the data made available in this article, unless otherwise stated in a credit line to the data. 
Table 1 Summary of clinical presentations of seven patients with circulatory collapse and unknown etiologies during or shortly after wound closure in spine surgery

\begin{tabular}{|c|c|c|c|c|}
\hline Case & $\begin{array}{l}\text { Demographic } \\
\text { information }\end{array}$ & $\begin{array}{l}\text { Initial signs/symptoms of shock and } \\
\text { management }\end{array}$ & $\begin{array}{l}\text { Hemoglobin } \\
\text { value }(\mathrm{g} / \mathrm{L}), \\
\text { fluid } \\
\text { resuscitation } \\
\text { and blood } \\
\text { product } \\
\text { infusion }\end{array}$ & $\begin{array}{l}\text { VCM administration } \\
\text { and Postoperative sequelae }\end{array}$ \\
\hline 1 & $\begin{array}{l}\text { Female; 68-yr; } 160 \\
\text { cm/60 kg } \\
\text { BMl: } 23.4 \\
\text { Diagnosis: } \\
\text { Lumbar stenosis (L3- } \\
\text { S1) } \\
\text { Surgery: } \\
\text { Posterior } \\
\text { decompression, } \\
\text { fixation and fusion } \\
\text { of lumbar spine. } \\
\text { Medical and allergy } \\
\text { history: } \\
\text { Hypertension } \\
\text { History of retina } \\
\text { surgery }\end{array}$ & $\begin{array}{l}\text { Time of occurrence: } \\
\text { Subcutaneous layer closure, } 30 \text { min after initiation } \\
\text { of wound closure. } \\
\text { Signs and symptoms: } \\
\text { ABP: } 30 / 20 \mathrm{mmHg} \\
\mathrm{SpO}_{2} \text { : undetectable } \\
\text { ECG: tarchycardia with elevated ST segment } \\
\text { Skin and airway symptoms: none. } \\
\text { Management: } \\
\text { Boluses and continuous infusion of noradrenaline } \\
(0.01-0.04 \mu \mathrm{g} / \mathrm{kg} / \mathrm{min}) \text { for } 45 \text { min. Fluid } \\
\text { resuscitation and blood transfusion. }\end{array}$ & $\begin{array}{l}\text { Preoperative } \\
\text { HGB value: } 124 \\
\text { Intraoperative } \\
\text { minimum value } \\
\text { of HGB: } 73 \\
\text { Blood loss: } 600 \\
\mathrm{ml} \\
\text { Urine: } 850 \mathrm{ml} \\
\text { Fluid and blood } \\
\text { product } \\
\text { infusion: } \\
\text { Crystalloid: } 3450 \\
\text { ml } \\
\text { Colloid: } 500 \mathrm{ml} \\
\text { PRBC infusion: } \\
\text { 1200 ml } \\
\text { Infused } \\
\text { autologous } \\
\text { blood: } 210 \mathrm{ml}\end{array}$ & $\begin{array}{l}\text { VCM administration: } \\
0.5 \mathrm{~g} \text { mixed with bone debris into the cage and } \\
0.5 \mathrm{~g} \text { spraying on the dura mater and into the } \\
\text { mascularis layer. } \\
\text { Postoperative sequelae: } \\
\text { Proceeded with surgery and the patient was } \\
\text { extubated uneventfully. }\end{array}$ \\
\hline 2 & $\begin{array}{l}\text { Male; } 74-y r ; 171 \mathrm{~cm} / \\
67 \mathrm{~kg} \\
\text { BMl: } 23.9 \\
\text { Diagnosis: } \\
\text { lumbar stenosis (L3- } \\
\text { 5) } \\
\text { Surgery: } \\
\text { Posterior } \\
\text { decompression, } \\
\text { fixation and fusion } \\
\text { of lumbar spine. } \\
\text { Medical and allergy } \\
\text { history: } \\
\text { nil relevant. }\end{array}$ & $\begin{array}{l}\text { Time of occurrence: } \\
\text { Subcutaneous layer closure, } 30 \text { min after initiation } \\
\text { of wound closure. } \\
\text { Signs and symptoms: } \\
\text { NBP: } 45 / 15 \mathrm{mmHg} \\
\mathrm{SpO}_{2} \text { : undetectable } \\
\text { ECG: tachycardia with ST segment depression } \\
\text { Skin and airway symptoms: none. } \\
\text { Management: } \\
\text { Boluses and continuous infusion of noradrenaline } \\
(0.05-0.4 \mu \mathrm{g} / \mathrm{kg} / \mathrm{min}) \text { and adrenaline }(0.5-0.15 \mu \mathrm{g} / \\
\mathrm{kg} / \mathrm{min}) \text { for } 4 \mathrm{~h} \text {. }\end{array}$ & $\begin{array}{l}\text { Preoperative } \\
\text { HGB value: } 135 \\
\text { Intraoperative } \\
\text { minimum value } \\
\text { of HGB: } 79 \\
\text { Blood loss: } 600 \\
\text { ml } \\
\text { Urine: } 1950 \mathrm{ml} \\
\text { Fluid and blood } \\
\text { product } \\
\text { infusion: } \\
\text { Crystalloid: } 6300 \\
\text { ml } \\
\text { Colloid: } 500 \mathrm{ml} \\
\text { PRBC infusion: } \\
\text { 1200 ml } \\
\text { Plasma: } 800 \mathrm{ml} \\
\text { Infused } \\
\text { autologous } \\
\text { blood: } 254 \mathrm{ml}\end{array}$ & $\begin{array}{l}\text { VCM administration: } \\
0.5 \mathrm{~g} \text { mixed with bone debris into the cage and } \\
0.5 \mathrm{~g} \text { spraying on the dura mater and into the } \\
\text { mascularis layer. } \\
\text { Postoperative sequelae: } \\
\text { The patient was extubated and transferred to ICU } \\
\text { due to neurological symptoms (unable to follow } \\
\text { instructions). } \\
\text { Postoperative imaging: intracranial minor } \\
\text { hemorrhage at subdural and subarachnoid space. } \\
\text { The patient was discharged from hospital without } \\
\text { neurological deficit. }\end{array}$ \\
\hline 3 & 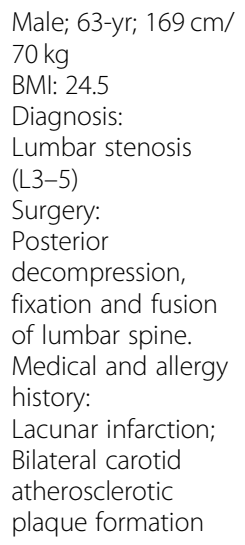 & $\begin{array}{l}\text { Time of occurrence: } \\
50 \text { min after initiation of wound closure and } 20 \\
\text { min post-extubation in the PACU. } \\
\text { Signs and symptoms: } \\
\mathrm{NBP}: 60 / 25 \mathrm{mmHg} \\
\mathrm{SpO} \mathrm{O}_{2}: 96 \% \\
\mathrm{HR}: \text { sudden elevation from } 60 \text { to } 90 \mathrm{bpm} \\
\text { Postoperative agitation } \\
\text { Skin and airway symptoms: none. } \\
\text { Management: } \\
\text { Boluses of ephedrine, phenylephrine and fluid } \\
\text { resuscitation. }\end{array}$ & $\begin{array}{l}\text { Preoperative } \\
\text { HGB value: } 176 \\
\text { Intraoperative } \\
\text { minimum value } \\
\text { of HGB:123 } \\
\text { Blood loss: } 800 \\
\text { ml } \\
\text { Urine: } 800 \mathrm{ml} \\
\text { Fluid and blood } \\
\text { product } \\
\text { infusion: } \\
\text { Crystalloid: } 2350 \\
\text { ml } \\
\text { Colloid: } 1000 \mathrm{ml} \\
\text { PRBC infusion: } \\
400 \mathrm{ml}\end{array}$ & $\begin{array}{l}\text { VCM administration: } \\
\text { Topical spraying of vancomycin }(1 \mathrm{~g}) \text { on the dura } \\
\text { mater and into the mascularis. } \\
\text { Postoperative sequelae: } \\
\text { Uneventful. }\end{array}$ \\
\hline 4 & $\begin{array}{l}\text { Female; } 70-y r ; 160 \\
\text { cm/ } 65 \mathrm{~kg} \\
\text { BMl: } 25.4\end{array}$ & $\begin{array}{l}\text { Time of occurrence: } \\
\text { Subcutaneous layer closure, } 30 \text { min after initiation } \\
\text { of wound closure. }\end{array}$ & $\begin{array}{l}\text { Preoperative } \\
\text { HGB value: } 150 \\
\text { Intraoperative }\end{array}$ & $\begin{array}{l}\text { VCM administration: } \\
0.5 \mathrm{~g} \text { mixed with bone debris into the cage and } \\
0.5 \mathrm{~g} \text { spraying on the dura mater and into the }\end{array}$ \\
\hline
\end{tabular}


Table 1 Summary of clinical presentations of seven patients with circulatory collapse and unknown etiologies during or shortly after wound closure in spine surgery (Continued)

\begin{tabular}{|c|c|c|c|c|}
\hline Case & $\begin{array}{l}\text { Demographic } \\
\text { information }\end{array}$ & $\begin{array}{l}\text { Initial signs/symptoms of shock and } \\
\text { management }\end{array}$ & $\begin{array}{l}\text { Hemoglobin } \\
\text { value }(\mathrm{g} / \mathrm{L}), \\
\text { fluid } \\
\text { resuscitation } \\
\text { and blood } \\
\text { product } \\
\text { infusion }\end{array}$ & $\begin{array}{l}\text { VCM administration } \\
\text { and Postoperative sequelae }\end{array}$ \\
\hline & $\begin{array}{l}\text { Diagnosis: } \\
\text { Lumbar stenosis (L4- } \\
\text { S1) } \\
\text { Surgery: } \\
\text { Posterior } \\
\text { decompression, } \\
\text { fixation and fusion } \\
\text { of lumbar spine. } \\
\text { Hypertension } \\
\text { Diabetes Mellitus }\end{array}$ & $\begin{array}{l}\text { Signs and symptoms: } \\
\text { NBP: } 45 / 15 \mathrm{mmHg} \\
\mathrm{SpO}_{2} \text { : undetectable } \\
\text { Persistent tachycardia } \\
\text { Skin and airway symptoms: none. } \\
\text { Management: } \\
\text { Boluses of phenylephrine for treating severe } \\
\text { hypotension and esmolol for tachycardia } \\
\text { Fluid resuscitation and blood transfusion. }\end{array}$ & $\begin{array}{l}\text { minimum value } \\
\text { of HGB: } 92 \\
\text { Blood loss: } 1500 \\
\text { ml } \\
\text { Urine: } 1800 \mathrm{ml} \\
\text { Fluid and blood } \\
\text { product } \\
\text { infusion: } \\
\text { Crystalloid: } 3100 \\
\text { ml } \\
\text { Colloid: } 1500 \mathrm{ml} \\
\text { PRBC infusion: } \\
\text { 1200 ml } \\
\text { Infused } \\
\text { autologous } \\
\text { blood: } 450 \mathrm{ml}\end{array}$ & $\begin{array}{l}\text { mascularis layer. } \\
\text { Postoperative sequelae: } \\
\text { The patient was extubated after surgery and } \\
\text { transferred to ICU due to tachycardia after } \\
\text { sufficient fluid resuscitation. } \\
\text { Recovered uneventfully. }\end{array}$ \\
\hline 5 & $\begin{array}{l}\text { Female; } 48-y r ; 170 \\
\text { cm/75 kg } \\
\text { BMI: } 26.0 \\
\text { Diagnosis: } \\
\text { Thoracic spinal canal } \\
\text { stenosis (T6-T11) } \\
\text { Surgery: } \\
\text { Posterior } \\
\text { decompression, } \\
\text { fixation and fusion } \\
\text { of thoracic spine. } \\
\text { Medical and allergy } \\
\text { history: } \\
\text { nil relevant. }\end{array}$ & $\begin{array}{l}\text { Time of occurrence: } \\
\text { Subcutaneous layer closure, } 30 \text { min after initiation } \\
\text { of wound closure. } \\
\text { Signs and symptoms: } \\
\text { NBP: } 40 / 30 \mathrm{mmHg} \text { to undetectable } \\
\mathrm{HR}: 120 \mathrm{bpm} \text { to } 40 \mathrm{bpm} \\
\mathrm{SpO}_{2} \text { : undetectable } \\
\text { Cardiac arrest } \\
\text { Skin and airway symptoms: none. } \\
\text { Management: } \\
\text { Extracardiac compression } \\
\text { Boluses of noradrenaline ( } 200 \mu \mathrm{g}) \text { and adrenaline } \\
(1 \mathrm{~g}) \\
\text { Continuous infusion of noradrenaline (0.02-- } \\
0.08 \mu \mathrm{g} / \mathrm{kg} / \mathrm{min}) \text { for } 50 \text { min } \\
\text { Fluid resuscitation and blood transfusion. }\end{array}$ & $\begin{array}{l}\text { Preoperative } \\
\text { HGB value: } 132 \\
\text { Intraoperative } \\
\text { minimum value } \\
\text { of HGB: } 74 \\
\text { Blood loss: } 2500 \\
\text { ml } \\
\text { Urine: } 1300 \mathrm{ml} \\
\text { Fluid and blood } \\
\text { product } \\
\text { infusion: } \\
\text { Crystalloid: } 4000 \\
\text { ml } \\
\text { Colloid: } 500 \mathrm{ml} \\
\text { PRBC infusion: } \\
2400 \mathrm{ml}\end{array}$ & $\begin{array}{l}\text { VCM administration: } \\
\text { Topical spraying of vancomycin }(1 \mathrm{~g}) \text { on the dura } \\
\text { mater and into the mascularis layer. } \\
\text { Postoperative sequelae: } \\
\text { The patient was extubated after surgery, and } \\
\text { discharged from hospital uneventfully. }\end{array}$ \\
\hline 6 & $\begin{array}{l}\text { Male; } 66-\mathrm{yr} ; 175 \mathrm{~cm} / \\
80 \mathrm{~kg} \\
\text { BMl: } 26.1 \\
\text { Diagnosis: } \\
\text { Lumbar stenosis } \\
\text { (L3-5) } \\
\text { Surgery: } \\
\text { Posterior } \\
\text { decompression, } \\
\text { fixation and fusion } \\
\text { of lumbar spine. } \\
\text { Medical and allergy } \\
\text { history: } \\
\text { Carotid artery } \\
\text { stenosis } \\
\text { Diabetes Mellitus }\end{array}$ & $\begin{array}{l}\text { Time of occurrence: } \\
\text { Sudden cardiac arrest } 10 \text { min after extubation } \\
\text { (approximately } 45 \mathrm{~min} \text { after initiation of wound } \\
\text { closure) with full recovery from anesthesia and } \\
\text { without any discomfort complaint. } \\
\text { Signs and symptoms: } \\
\text { Cardiac arrest and persistent VF } \\
\text { Skin and airway symptoms: none. } \\
\text { Management: } \\
\text { Continuous CPR } \\
\text { Persistent VF was treated with repeated } \\
\text { defibrillation } \\
\text { Boluses of adrenaline (a total of } 6 \mathrm{mg} \text { ) and } \\
\text { amiodarone. } \\
\text { Fluid resuscitation and blood transfusion. }\end{array}$ & $\begin{array}{l}\text { Preoperative } \\
\text { HGB value: } 143 \\
\text { Intraoperative } \\
\text { minimum value } \\
\text { of HGB: } 78 \\
\text { Blood loss: } 1000 \\
\text { ml } \\
\text { Urine: } 850 \mathrm{ml} \\
\text { Fluid and blood } \\
\text { product } \\
\text { infusion: } \\
\text { Crystalloid: } 4400 \\
\text { ml } \\
\text { Colloid: } 1000 \mathrm{ml} \\
\text { PRBC infusion: } \\
\text { 1200 ml } \\
\text { Infused } \\
\text { autologous } \\
\text { blood: } 600 \mathrm{ml}\end{array}$ & $\begin{array}{l}\text { VCM administration: } \\
\text { Topical spraying of vancomycin ( } 3 \mathrm{~g} \text { ) on the dura } \\
\text { mater and into the mascularis. } \\
\text { Postoperative sequelae: } \\
\text { The patient was reintubated and transferred to } \\
\text { ICU after ROSC. The patient was diagnosed as } \\
\text { hypoxic encephalopathy and remained in a coma } \\
\text { state. Tracheotomy was performed } 2 \text { weeks after } \\
\text { surgery, and the patient was transferred to a } \\
\text { nursing home for rehabilitation } 1 \text { month after } \\
\text { orthopedic surgery. }\end{array}$ \\
\hline 7 & $\begin{array}{l}\text { Female; } 43-y r ; 155 \\
\text { cm / } 54 \mathrm{~kg} \\
\text { BMI: } 22.4 \\
\text { Diagnosis: } \\
\text { Thoracic kyphosis } \\
\text { (T7-T8) } \\
\text { Surgery: } \\
\text { Osteotomy for }\end{array}$ & $\begin{array}{l}\text { Time of occurrence: } \\
\text { subcutaneous layer closure, } 30 \text { min after initiation } \\
\text { of wound closure. } \\
\text { Signs and symptoms: } \\
\text { HR:tachycardia } \\
\mathrm{NBP:} 60 / 30 \mathrm{mmHg} \\
\mathrm{SpO}_{2} 82 \% \\
\text { Skin and airway symptoms: none. }\end{array}$ & $\begin{array}{l}\text { Preoperative } \\
\text { HGB value: } 138 \\
\text { Intraoperative } \\
\text { minimum value } \\
\text { of HGB: } 95 \\
\text { Blood loss: } 1200 \\
\text { ml } \\
\text { Urine: } 1900 \mathrm{ml}\end{array}$ & $\begin{array}{l}\text { VCM administration: } \\
\text { Topical spraying of vancomycin ( } 1 \mathrm{~g}) \text { on the dura } \\
\text { mater and into the mascularis layer. } \\
\text { Postoperative sequelae: } \\
\text { The patient was transferred to ICU for optimal } \\
\text { monitoring and recovered uneventfully. }\end{array}$ \\
\hline
\end{tabular}


Table 1 Summary of clinical presentations of seven patients with circulatory collapse and unknown etiologies during or shortly after wound closure in spine surgery (Continued)

\begin{tabular}{|c|c|c|c|c|}
\hline Case & $\begin{array}{l}\text { Demographic } \\
\text { information }\end{array}$ & $\begin{array}{l}\text { Initial signs/symptoms of shock and } \\
\text { management }\end{array}$ & $\begin{array}{l}\text { Hemoglobin } \\
\text { value }(\mathrm{g} / \mathrm{L}), \\
\text { fluid } \\
\text { resuscitation } \\
\text { and blood } \\
\text { product } \\
\text { infusion }\end{array}$ & $\begin{array}{l}\text { VCM administration } \\
\text { and Postoperative sequelae }\end{array}$ \\
\hline & $\begin{array}{l}\text { kyphosis of thoracic } \\
\text { spine (T7-T8). } \\
\text { Medical and allergy } \\
\text { history: } \\
\text { nil relevant. }\end{array}$ & $\begin{array}{l}\text { Management: } \\
\text { Boluses of phenylephrine and ephedrine; } \\
\text { Continuous infusion of noradrenaline }(0.05- \\
0.1 \mu \mathrm{g} / \mathrm{kg} / \mathrm{min}) \\
\text { Fluid resuscitation and blood transfusion. }\end{array}$ & $\begin{array}{l}\text { Fluid and blood } \\
\text { product } \\
\text { infusion: } \\
\text { Crystalloid: } 4700 \\
\text { ml } \\
\text { Colloid: } 1000 \mathrm{ml} \\
\text { PRBC infusion: } \\
1200 \mathrm{ml} \\
\text { Infused } \\
\text { autologous } \\
\text { blood: } 470 \mathrm{ml}\end{array}$ & \\
\hline
\end{tabular}

Abbreviations: NBP Non-invasive blood pressure; $A B P$ Arterial blood pressure; (NBP is noted when ABP is not available.) VF Ventricular fibrillation; $C P R$ Cardiopulmonary Resuscitation; HGB Hemoglobin; VCM Vancomycin; PRBC Packed red blood cell; ROSC Return of spontaneous circulation

shortly after spine surgery, and discuss the possible reasons.

\section{Case presentation}

The first case we encountered was a 68 -yr female with past medical history of hypertension and surgical treated retina detachment, who underwent posterior decompression, fixation and fusion of lumbar spine due to lumbar stenosis (L3-S1). The operation was uneventful until sudden circulatory collapse occurred during the process of rinsing mascularis and superficial fascia layer whilst closing the wound. A sudden drop in arterial blood pressure (ABP) (130/60 $\mathrm{mmHg}$ to $30 / 20 \mathrm{mmHg}$ ), increased HR (60 bpm to $100 \mathrm{bpm})$ with elevated STsegment and significant decrease of $\mathrm{PetCO}_{2}(31 \mathrm{mmHg}$ to $16 \mathrm{mmHg}$ ) were noticed, with undetectable pulse oximetry read. The patient was turned to supine position immediately and managed with boluses (40-100 $\mu \mathrm{g})$ and a continuous infusion of noradrenaline $(0.01-0.04 \mu \mathrm{g} /$ $\mathrm{kg} / \mathrm{min}$ ) for approximately $45 \mathrm{~min}$. The circulation was gradually stabilized. No rash, erythema, or bronchospasm were noted. The bilateral breath sounds were equal and the airway pressure remained normal. We continued treatments of fluid resuscitation and blood transfusion with corticosteroid and ice cap to prevent hypoxic-ischemic encephalopathy. Intraoperative emergency consultations and immediate examinations of 12lead ECG, point-of-care transthoracic echocardiography (TTE), and full panel laboratory tests were performed. However, these results did not support the causes of sudden cardiac dysfunction (the pump) including mechanical obstruction (pericardial tamponade and massive pulmonary embolus), acute myocardial infarction, acute valvular insufficiency, and arrhythmia. Vascular catastrophes were excluded and there were no signs of sepsis.
We also examined the intravascular volume function (the tank) by performing the TTE, and ruled out intraperitoneal major hemorrhage which we once encountered (caused by inadvertent piercing of iliac artery when placing probe during lumbar surgery) by examination of abdominal ultrasound and hemoglobin level; Volume status was evaluated by measuring CVP, urine output, infused fluid volume; Surgical blood loss was reviewed to exclude hemorrhage shock and hypovolemia. As no special medications were given except anesthetic maintenance drugs, and no signs of mottled skin or bronchospasm were noticed, anaphylaxis was not considered at that time. After restoring circulatory stability, the surgery preceded uneventfully. The patient was discharged from hospital 7 days later.

It was intriguing that within 1 month, another case of circulatory collapse happened during wound closure in spine surgery performed by the same orthopedic surgeon. The intraoperative clinical manifestations were very similar to the previous one. Hemodynamic resuscitation were initiated immediately with repeated boluses and continuous infusion of noradrenaline $(0.05-0.4 \mu \mathrm{g} /$ $\mathrm{kg} / \mathrm{min})$ and adrenaline $(0.5-0.15 \mu \mathrm{g} / \mathrm{kg} / \mathrm{min})$. After stabilizing the circulation $4 \mathrm{~h}$ later, the patient was extubated and transferred to ICU due to neurological symptoms (unable to follow instructions after full recovery from anesthesia). Postoperative imaging revealed intracranial micro hemorrhagic foci in the subdural and subarachnoid space. The patient was discharged from hospital without any neurological sequelae.

With further exploration and analysis of the similarities of these two cases, we found that local application of vancomycin (VCM) powder was used in these two patients to prevent postoperative surgical site infections (SSIs) during wound closure $(0.5 \mathrm{~g}$ VCM loaded with 
bone debris into the cage and another $0.5 \mathrm{~g}$ sprayed on the dura mater and into the mascularis). Ramamani Mariappan reported a case of circulatory collapse after topical application of vancomycin powder during spine surgery, which exhibited almost the same clinical course as ours [2]. It was speculated that the rapid absorption of VCM applied to the surgical wound caused an anaphylaxis reaction and circulatory collapse. The reaction occurred approximately $30 \mathrm{~min}$ after the application and persisted for $6 \mathrm{~h}$. The serum tryptase level was not elevated, suggesting that VCM caused a direct histamine release, which is in keeping with our current understanding. A similar case reported a 74-year-old woman who underwent a primary total knee replacement presented with red man syndrome in the PACU $45 \mathrm{~min}$ after release of tourniquet following the use of VCMloaded bone cement. The patient remained fully conscious despite a sudden drop in blood pressure to $47 / 34$ $\mathrm{mmHg}$ [3]. Therefore, local application of VCM may pose the risk of causing severe circulatory adverse effect.

Similar circulatory collapse cases in spine surgery without definitive causes during wound closure or shortly after surgery, though rare, were encountered in our institution. Therefore we retrospectively analyzed these cases for the past 2 years, and asked the anesthesiologists and orthopedic surgeons in charge for further information. A total of 7 cases were collected (Table 1). There were 3 males and 4 females, the median age was 66 y $(43-74 \mathrm{y})$, and the averaged BMI was $24.39 \pm 1.51(22.3-26.1)$. It was interesting to note that these cases were all associated with topical application of VCM powder (Table 1). In these 7 cases, the onset time of severe circulatory fluctuation was $30 \mathrm{~min}$ in 5 cases, $50 \mathrm{~min}$ in one case (applied with $1 \mathrm{~g}$ of $\mathrm{VCM}$ ), and approximately $45 \mathrm{~min}$ in another case (locally applied $3 \mathrm{~g}$ of $\mathrm{VCM}$ ), respectively. Most of the cases (6/7) with severe circulatory fluctuation were corrected without severe sequelae. While in one case in which $3 \mathrm{~g}$ of VCM was applied on the dura mater and into the mascularis during wound closure, sudden cardiac arrest happened shortly after the patient had fully recovered from the anesthetic, following surgery and extubation in the OR. CPR was initiated immediately. The patient was reintubated and ventilated mechanically. The persistent VF was treated with continuous chest compressions and repeated defibrillation, with boluses of adrenaline (a total of $6 \mathrm{mg}$ ) and amiodarone. After 50 min of continuous CPR, with fluid resuscitation and blood transfusion, the patient was transferred to ICU following the return of spontaneous circulation and reverting into sinus rhythm. However, the patient remained in a comatose state due to hypoxic-hypoxic encephalopathy, and tracheotomy was performed 2 weeks later.

\section{Discussion and conclusion}

\section{Vancomycin and anaphylaxis reaction}

"International Consensus on (ICON) Anaphylaxis" define anaphylaxis as "a serious, generalized or systemic, allergic or hypersensitivity reaction that can be life threatening or fatal" [4]. It has been demonstrated that there exists IgE-dependent and three IgE-independent mechanisms in anaphylaxis pathophysiology [5]. VCM could directly activate mast cells to release histamine and other mediators through an IgE-independent mechanism that is calcium-, phospholipase $\mathrm{C}_{-}$, and phospholipase A2-dependent but otherwise unknown $[5,6]$. Vancomycin-induced direct histamine release is also infusion rate dependent [7]. This IgE-independent anaphylaxis reaction generally disappears within 20 mins, but may linger for hours. The most common manifestation is a sudden drop in blood pressure, which is related to the negative inotropic effect and the vasodilator action stimulated by the histamine release. Alteration in vascular tone is also a common feature of anaphylactic shock [8]. Richter J and colleagues demonstrated in rats that VCM could directly influence the vascular tonus, affecting the microcirculation [9].

The VCM reactions studied in the pediatric population revealed that non-IgE mediated reaction accounts for the vast majority of reactions (92\%; prevalence, 5.4$5.8 \%)$, whereas possible IgE-mediated vancomycin reactions were exceedingly rare (prevalence, $0.0-0.37 \%$ ) [7]. For adults, the reported incidence of non-IgE mediated reaction varies between 3.7 and $47 \%$ in infected patients and $90 \%$ in healthy volunteers [2]. Elevated serum mast cell tryptase is a valuable indicator for diagnosing Ig-E mediated anaphylactic reaction. However, it is not useful in determining a non-IgE mediated anaphylactic reaction caused by histamine release [2]. Detection of histamine concentration in clinical blood specimens is difficult due to its extremely short half-life, and histamine is not a mast cell specific product [10]. As this study is retrospective in nature, and our hospital does not perform examination of serum tryptase and histamine concentration, we could not differentiate whether the adverse effects were caused by VCM induced IgE-mediated or non-IgE mediated reaction.

\section{Topical application of vancomycin powder and surgical site infections}

VCM is effective in fighting Gram-positive bacteria related severe infections [11]. While the actual utility of local application of VCM is controversial. After the first reported topical application of VCM by orthopedic surgeons to reduce postoperative surgical site infections (SSIs) rate [12], a large number of meta-analyses, retrospective cohort studies, and randomized controlled trials were published to assess the power of this method in 
preventing SSIs. Recent findings from large-scale propensity score matched analyses, meta analyses, RCTs studies, and observational studies of spine surgeries and knee arthroplasties all demonstrated that the intrawound VCM powder application may not decrease SSIs, but may increase postoperative complications [13-19].

$\mathrm{VCM}$ is an antibiotic that was considered safe in local application and has been widely used in hospitals. However, dose recommendations, dilutions, monitoring, infusion types and rates are still controversial [20]. There's no defined time or situation during surgery when local VCM should be applied. Some may load VCM powder with bone debris into the cage, or apply VCM powder directly onto the dura mater or after closure of the fascia, whereas other studies reported that VCM powder was applied in the subfascial layer [2, 13]. However, intrawound absorption rate of VCM powder is uncontrollable as this depends on multiple factors, such as the extent and degree of tissue/muscle damaged by surgical manipulation, anatomic location where VCM powder is placed (mixed with bone debris, or between muscularis layers that are abundant with blood supply), and the surgeon's suturing maneuvers (the flushing saline would leak from upper layer into the layer where VCM powder is deposited). These factors all pose potential risk of causing rapid drug dissolution and accelerated absorption into the circulatory system. Moreover, individual's adverse reactions to VCM varied. These incidental events may be accidentally linked and lead to severe outcome. Since intravenous administration of VCM could lead to adverse effects, it is theoretically possible that local application of VCM powder may cause similar clinical manifestation.

Topical application of VCM was intended to achieve the effect of providing high local concentrations while avoiding high systemic levels and the risk of bacterial resistance. The serum concentration level peaks at $30 \mathrm{~min}$ and then declines to baseline at $6 \mathrm{~h} \mathrm{[2].} \mathrm{This} \mathrm{may} \mathrm{explain}$ the delayed and unpredictable occurrence of anaphylaxis reactions after local application of VCM powder, due to the uncertainty of the drug absorption rate and individual reaction differences. The instructed therapeutic dosage of VCM is $30 \mathrm{mg} / \mathrm{kg} /$ day which should be fractioned in 2 or 3 doses. Moreover, the infusion rate should be within $10 \mathrm{mg} / \mathrm{min}$, and last for more than $60 \mathrm{~min}$. For elderly patients, this dosage should be reduced [21, 22]. Although the most commonly used dose of intrawound VCM is $1 \mathrm{~g}$, some authors reported that they altered the dose according to the length of the incision [23]. VCM is not the first-choice antibiotic as its adverse effects are frequently reported including hypotension and tachycardia, phlebitis, nephrotoxicity, ototoxicity, hypersensitivity reactions, red man syndrome, neutropenia, chills, fever, interstitial nephritis, etc. [13]. As VCM induced adverse reactions are dose and infusion-rate dependent, doctors should be highly vigilant to over-dosing which might bring disastrous results.

\section{Other issues related to shock}

In this case series, the typical signs of erythema and redness (red man syndrome) have not appeared, which resemble the previous case reported by Mariappan $\mathrm{R}$ and colleagues [2]. The lack of skin flushing may be the result of reduced perfusion due to circulatory shock or the adverse effect of VCM mainly manifested as severe alteration of vascular tonus $[8,9]$. In our experience, a rapid but low dose intravenous infusion of VCM induced anaphylaxis reaction was not necessarily associated with skin manifestations. Whether this is related to racial differences or rapid absorption of low dose VCM was not known. However, the clinical features of hypotension, tachycadia and low oxygenation were notable.

For this case series, as there is no definitive laboratory examination or gold standard to help reach a definitive diagnosis of VCM induced anaphylaxis reaction, the conclusions were made upon differential diagnosis based on clinical manifestations and the timing of the shock. Other possible causes or contributing factors for the development of severe hypotension and shock need to be considered. For example, restrictive fluid therapy during surgical procedure and restrictive blood transfusion strategy leading to hypovolemia and hypotension, complicated with unseen bleeding from surgical site and other compounding factors such as hypoproteinemia and unaltered anesthetic depth during wound closure.

Another issue needs to be addressed is that there's a notable decrease in hemoglobin (HGB) concentration in all cases when severe hypotension occurred. However, the hemorrhagic shock induced by surgical blood loss was ruled out. We speculate that this might be due to the infusion of large amounts of fluid during resuscitation. It is reported that the administration of $500 \mathrm{ml}$ of fluids may acutely decrease the HGB concentration by about $1 \mathrm{~g} / \mathrm{dl}$, or about $8 \%$, by "dilutional anemia" [24]. In septic shock patients, approximately $30 \%$ decrease of hematocrit was commonly observed in patients receiving large amounts of fluids during resuscitation, which further indicates more blood transfusion [25]. In the current study, the HGB concentrations were all measured after the initiation of fluid resuscitation and this may at least partially explained the sharp decrease of the HGB level (Table 1). When severe hypotension with unknown causes occur, initial management is to infuse large amounts of fluid with vaso-constrictive drugs. The iatrogenic hemodilution related blood transfusion may result in dilutional coagulopathy and increase surgical bleeding. This then leads to a decreased HGB level below the acceptable transfusion threshold, leading to 
further blood transfusion in the absence of significant blood loss [26]. This is especially true when in the scenario of the existence of suspected hemorrhagic shock.

In conclusion, local application of VCM powder during wound closure could cause delayed occurrence of severe hypotension and shock in spine surgery. Hemodynamic changes may be under-emphasized and under-reported as in most cases, this hemodynamic reaction is easy to correct and normally wouldn't cause serious consequences. However, the actual occurrence is not rare and this might be confused with hypovolemia or anesthetic induced hypotension. Surgeons and anesthesiologists should be highly aware of VCM induced IgE-independent anaphylaxis reactions. The differential diagnosis of anaphylactic shock must be taken into consideration in patients with acute hypotension during or immediately after wound closure. Prompt laboratory analysis of serum tryptase and histamine concentration could help differentiate the causes. Moreover, since controversies still exist in the actual effect of intrawound application of VCM powder to reduce SSIs in spine surgery, local application of this drug should be used with caution.

\section{Abbreviations \\ VCM: Vancomycin; ABP: Arterial blood pressure; TTE: Transthoracic echocardiography}

\section{Acknowledgments}

We sincerely thank our colleagues from anesthesia (Dr. XW, Dr. CW, Dr. WL, Dr. JY, Dr. YW, Dr. CN, Dr. CX, Dr. YT, Dr. HW, Dr. HT, Dr. WW, Dr. YT, Dr. XJ, $H L$, Dr. HW, Dr. HZ, Dr. YW, and Dr. BW) and surgical department (Dr. YD, Dr. YL, Dr. FZ, Dr. QQ, and Dr. ZC) for providing and verifying the cases.

The authors have completed the CARE reporting checklist.

\section{Authors' contributions}

Guarantor of integrity of entire study: XZ, WZ, ML, XG. Literature research: XZ, WZ. Case study and follow-up: XZ, WZ. Manuscript preparation: XZ, WZ. Manuscript editing and revision: ML, XG. Manuscript final version approval: ML, XG. All authors have read and approved the manuscript.

\section{Funding}

This work was supported by the Clinical Key Project of Peking University Third Hospital, Grants No. BYSY2017001.

The role of the funder: study design, decision to submit the manuscript for publication.

\section{Availability of data and materials}

All data generated or analyzed during this study are included in this published article. More detailed information could be find in Table 1.

\section{Ethics approval and consent to participate}

This case was performed according to the ethical guidelines of the Helsinki Declaration and was approved by the Human Ethics Committee of Peking University Third Hospital. All the authors listed in the manuscript consent to participate the study. The consent for publication from patient or their relatives were collected retrospectively.

\section{Consent for publication}

As this is a retrospective case study, written informed consent to publish this manuscript were collected from patients or their relatives retrospectively. The proof of consent to publish from study participants can be requested at any time.

\section{Competing interests}

The author(s) declare no competing interests.

Received: 22 September 2020 Accepted: 15 December 2020

Published online: 06 January 2021

\section{References}

1. Wacker DA, Winters ME. Shock. Emerg Med Clin North Am. 2014;32(4):74758. https://doi.org/10.1016/j.emc.2014.07.003.

2. Mariappan R, Manninen P, Massicotte EM, Bhatia A. Circulatory collapse after topical application of vancomycin powder during spine surgery. J Neurosurg Spine. 2013;19(3):381-3. https://doi.org/10.3171/2013.6. SPINE1311.

3. Chen CT, Ng KJ, Lin Y, Kao MC. Red man syndrome following the use of vancomycin-loaded bone cement in the primary total knee replacement: a case report. Medicine (Baltimore). 2018;97(51):e13371. https://doi.org/10. 1097/MD.0000000000013371?.

4. Simons FE, Ardusso LR, Bilò MB, et al. International consensus on (ICON) anaphylaxis. World Allergy Organ J. 2014;7(1):9. Published 2014 May 30. https://doi.org/10.1186/1939-4551-7-9.

5. Finkelman FD, Khodoun MV, Strait R. Human IgE-independent systemic anaphylaxis. J Allergy Clin Immunol. 2016;137(6):1674-80. https://doi.org/10. 1016/j.jaci.2016.02.015

6. Veien M, Szlam F, Holden JT, Yamaguchi K, Denson DD, Levy JH. Mechanisms of nonimmunological histamine and tryptase release from human cutaneous mast cells. Anesthesiology. 2000;92(4):1074-81. https:// doi.org/10.1097/00000542-200004000-00026.

7. Lin SK, Mulieri KM, Ishmael FT. Characterization of Vancomycin reactions and linezolid utilization in the pediatric population. J Allergy Clin Immunol Pract. 2017;5(3):750-6. https://doi.org/10.1016/j.jaip.2016.12.022.

8. De Bisschop MB, Bellou A. Anaphylaxis. Curr Opin Crit Care. 2012;18(4):30817. https://doi.org/10.1097/MCC.0b013e3283557a63.

9. Richter J, Zhou J, Pavlovic D, et al. Vancomycin and to lesser extent tobramycin have vasomodulatory effects in experimental endotoxemia in the rat. Clin Hemorheol Microcirc. 2010;46(1):37-49. https://doi.org/10.3233/ $\mathrm{CH}-2010-1331$

10. Reber LL, Hernandez JD, Galli SJ. The pathophysiology of anaphylaxis. J Allergy Clin Immunol. 2017;140(2):335-48. https://doi.org/10.1016/j.jaci.2017. 06.003 .

11. Bruniera FR, Ferreira FM, Saviolli LR, et al. The use of vancomycin with its therapeutic and adverse effects: a review. Eur Rev Med Pharmacol Sci. 2015; 19(4):694-700.

12. Sweet FA, Roh M, Sliva C. Intrawound application of vancomycin for prophylaxis in instrumented thoracolumbar fusions: efficacy, drug levels, and patient outcomes. Spine (Phila Pa 1976). 2011;36(24):2084-8. https://doi. org/10.1097/BRS.0b013e3181ff2cb1.

13. Horii C, Yamazaki T, Oka H, et al. Does intrawound vancomycin powder reduce surgical site infection after posterior instrumented spinal surgery? A propensity score-matched analysis. Spine J. 2018;18(12):2205-12. https://doi. org/10.1016/j.spinee.2018.04.015.

14. Gande A, Rosinski A, Cunningham T, Bhatia N, Lee YP. Selection pressures of vancomycin powder use in spine surgery: a meta-analysis. Spine J. 2019; 19(6):1076-84. https://doi.org/10.1016/j.spinee.2019.01.002.

15. Tubaki VR, Rajasekaran S, Shetty AP. Effects of using intravenous antibiotic only versus local intrawound vancomycin antibiotic powder application in addition to intravenous antibiotics on postoperative infection in spine surgery in 907 patients. Spine (Phila Pa 1976). 2013;38(25):2149-55. https:// doi.org/10.1097/BRS.0000000000000015.

16. Mirzashahi B, Chehrassan M, Mortazavi SMJ. Intrawound application of vancomycin changes the responsible germ in elective spine surgery without significant effect on the rate of infection: a randomized prospective study. Musculoskelet Surg. 2018;102(1):35-9. https://doi.org/10.1007/s12306017-0490-z.

17. Martin JR, Adogwa $\mathrm{O}$, Brown $C R$, et al. Experience with intrawound vancomycin powder for spinal deformity surgery. Spine (Phila Pa 1976). 2014;39(2):177-84. https://doi.org/10.1097/BRS.0000000000000071.

18. Hanada M, Nishikino S, Hotta K, Furuhashi H, Hoshino H, Matsuyama Y. Intrawound vancomycin powder increases post-operative wound complications and does not decrease periprosthetic joint infection in primary total and unicompartmental knee arthroplasties. Knee Surg Sports 
Traumatol Arthrosc. 2019;27(7):2322-7. https://doi.org/10.1007/s00167-01905498-z.

19. Yavuz IA, Oken OF, Yildirim AO, Inci F, Ceyhan E, Gurhan U. No effect of vancomycin powder to prevent infection in primary total knee arthroplasty: a retrospective review of 976 cases [published online ahead of print, 2019 Nov 14]. Knee Surg Sports Traumatol Arthrosc. 2019. https://doi.org/10.1007/ s00167-019-05778-8.

20. Bakhsheshian J, Dahdaleh NS, Lam SK, Savage JW, Smith ZA. The use of vancomycin powder in modern spine surgery: systematic review and metaanalysis of the clinical evidence. World Neurosurg. 2015;83(5):816-23. https://doi.org/10.1016/j.wneu.2014.12.033.

21. Hicks RW, Hernandez J. Perioperative pharmacology: a focus on vancomycin. AORN J. 2011;93(5):593-9. https://doi.org/10.1016/j.aorn.2010. 09.031.

22. Badran EF, Shamayleh A, Irshaid YM. Pharmacokinetics of vancomycin in neonates admitted to the neonatology unit at the Jordan University hospital. Int J Clin Pharmacol Ther. 2011;49(4):252-7. https://doi.org/10.5414/ CP201456

23. Chotai S, Wright PW, Hale AT, et al. Does Intrawound Vancomycin application during spine surgery create Vancomycin-resistant organism? Neurosurgery. 2017;80(5):746-53. https://doi.org/10.1093/neuros/nyw097.

24. Monnet X, Julien F, Ait-Hamou N, et al. Lactate and venoarterial carbon dioxide difference/arterial-venous oxygen difference ratio, but not central venous oxygen saturation, predict increase in oxygen consumption in fluid responders. Crit Care Med. 2013;41(6):1412-20. https://doi.org/10.1097/CCM. 0b013e318275cece.

25. Jha V, Gutierrez G. Severe sepsis and septic shock: should blood be transfused to raise mixed venous oxygen saturation? Chest. 2007;131(4): 1267-9. https://doi.org/10.1378/chest.06-2891.

26. Perel A. latrogenic hemodilution: a possible cause for avoidable blood transfusions? Crit Care. 2017;21(1):291. Published 2017 Nov 25. https://doi. org/10.1186/s13054-017-1872-1.

\section{Publisher's Note}

Springer Nature remains neutral with regard to jurisdictional claims in published maps and institutional affiliations.

Ready to submit your research? Choose BMC and benefit from:

- fast, convenient online submission

- thorough peer review by experienced researchers in your field

- rapid publication on acceptance

- support for research data, including large and complex data types

- gold Open Access which fosters wider collaboration and increased citations

- maximum visibility for your research: over $100 \mathrm{M}$ website views per year

At $\mathrm{BMC}$, research is always in progress.

Learn more biomedcentral.com/submissions 